\title{
Molecular differences between GM- and non-GM crops over-estimated?
}

\author{
Klaus Ammann \\ AF-10 20101228 opensource, New update from 28. December 2010
}

\author{
Correspondence Author: \\ klaus.ammann@ips.unibe.ch \\ Peer reviewed contribution available on the following websites: \\ Public Research Initiative: www.pubresreg.org \\ European Federation of Biotechnology: http://www.efb-central.org/
}

S. No. Title

1.0. Issue

2.0. Summary

3.0. Differences between GM- and non-GM-crops overestimated

3.1. Early phase of risk assessment: Discovery of the dynamics of DNA processes.

3.2. Molecular processes similar in natural mutation and transgenesis

3.3. More recent publications about genomic comparisons of GM- and non-GM crops

4.0. Natural Genetically Modified Plants, DNA as a highly dynamic system

4.1. Dramatic rearrangement of $\mathrm{R}$ gene loci: This class of genes diversifies more rapidly than other genes in the crops studies

4.2. Jumping Genes: Their dynamics falsify the erroneous picture of regulators that DNA is a stable string of genes

4.3. Helitrons contribute to the lack of gene colinearity observed in modern maize inbreds

4.4. Polyploids, Alloploids in Flowering Plants

4.5. Horizontal Geneflow between Pro-Caryotes and Eu-Caryotes

5.0. Some conventional breeding causes lots of genomic alteration

6.0. Regulatory dissent over molecular differences causes transatlantic divide

6.1. Perspectives for a dissolution of this divide

7.0. Conclusion

8.0. Cited literature

\subsection{Issue}

The difference between GM- and non-GM-crops has been overestimated, as soon as genetic engineering has been applied to crop breeding. The uncontested understanding among scientists and in particular in risk assessment community was that GM crops pose some novel risks, unprecedented in conventionally bred crops. This has then condensed in the United Nations Cartagena Protocol on Biosafety ${ }^{1}$, which needs to be questioned in certain basic aspects.

${ }^{1}$ Cartagena Protocol on Biosafety: http://www.cbd.int/biosafety/

\subsection{Summary}

Page No.

31

31

32

32

32

33

36

36

38

39

39

40

40

41

41

42

42

After an early phase of risk assessment, including the results of the Asilomar Conference on biosafety, an early divide in risk assessment basic concepts developed between Canada, the USA and Europe including a majority of UN signatory countries. Researchers like Werner Arber, based on earlier molecular insights and on his own experience in genetic engineering claim that related to molecular processes there is no difference between genetically engineering and natural mutation. This transatlantic 
divide can be solved with some more innovative regulatory proceedings.

\subsection{Differences between GM- and non-GM-crops overestimated}

\subsection{Early phase of risk assessment: Discovery of the dynamics of DNA processes.}

In the wake of molecular breeding, in particular with the first successes of "gene splicing", the safety debates started soon after the discovery of the DNA structure by Watson \& Crick (Watson \& Crick, 1953a, b; Wilkins et al., 1953), followed by the Asilomar Conference (Berg et al., 1975; Berg \& Singer, 1995) see also some historical accounts (Chassy, 2007; Friedberg, 2007; Klug, 2004). The fascination about the novelty of transgenesis was justified, but also overwhelming, and the many unforeseen scientific breakthroughs following were unprecedented in the history of molecular biology. Unfortunately, the enthusiasm also lashed back in an overacting in risk assessment, when the first GM crops went into production. The debate on how GM crops should be regulated, started very early with an emerging divide between regulation in the US and Great Britain, including later the whole of Europe (Bennett et al., 1986; National-Research-Council, 1989).

The seemingly absolute novelty of genetic engineering on the molecular level has been contested already in the early days of molecular biology in the 1930s and 1950 s with the discovery of cellular systems for genome restructuring discovered with the classic papers of McClintock (McClintock, 1930, 1953), more details about jumping genes see chapter 4.2 .

\subsection{Molecular processes similar in natural mutation and transgenesis}

The concept of violated intrinsic naturalness of the genomes is still erroneously maintained by proponents of organic farmers (van Bueren et al., 2008; Van Bueren \& Struik, 2004, 2005; Van Bueren et al., 2003). This concept of singling out transgenity is falsified by the publications of Arber (Nobel Laureate 1978).

Genetic engineering has been brought into evolutionary perspective of natural mutation by authorities such as Werner Arber: his view remains scientifically uncontested that molecular processes in transgenesis and natural mutation are basically similar (Arber, 1994, 2000, 2002, 2003, 2004; Arber, 2010). The same claim is made with a more organismal view by Hackett (Hackett, 2002).

Arber compared designed genetic alterations (including genetic engineering) with the spontaneous genetic variation known to form the substrate for biological evolution (Arber, 2002):

"Site-directed mutagenesis usually affects only a few nucleotides. Still another genetic variation sometimes produced by genetic engineering is the reshuffling of genomic sequences, e.g. if a given open reading frame is brought under a different signal for expression control or if a gene is knocked out. All such changes have little chance to change in fundamental ways, the properties of the organism. In addition, it should be remembered that the methods of molecular genetics themselves enable the researchers anytime to verify whether the effective genomic alterations correspond to their intentions, and to explore the phenotypic changes due to the alterations. This forms part of the experimental procedures of any research seriously carried out. Interestingly, naturally occurring molecular evolution, i.e. the spontaneous generation of genetic variants has been seen to follow exactly the same three strategies as those used in genetic engineering. These three strategies are:

(a) small local changes in the nucleotide sequences,

(b) internal reshuffling of genomic DNA segments, and

(c) acquisition of usually rather small segments of DNA from another type of organism by horizontal gene transfer.

However, there is a principal difference between the procedures of genetic engineering and those serving in nature for biological evolution. While the genetic engineer prereflects his alteration and verifies its results, nature places its genetic variations more randomly and largely independent of an identified goal. Under natural conditions, it is the pressure of natural selection which eventually determines, together with the available diversity of genetic variants, the direction taken by evolution. It is interesting to note that natural selection also plays its decisive role in genetic engineering, since indeed not all pre-reflected sequence alterations withstand the power of natural selection. Many investigators have experienced the effect of this natural force which does not allow functional disharmony in a mutated organism."

Arbers numerous writings (Arber, 2000, 2003, 2004) confirm this important comparison on the genomic level of evolutionary and modern plant breeding processes. But there is of course, despite all the similarities, one major difference: whereas natural mutation acts completely in a natural time scale, that is, the mutants will need hundreds to hundred of 
thousands of years to overcome selective processes in nature until they really succeed and take over against their natural competitors, this is totally different with the transgenic crop products: they run through a R\&D phase, and a regulatory process of an average of 15 to 20 years until being completely deregulated. But somewhere along this process they will be propagated to the millions in the field, covering in a evolutionary extremely short time span millions of hectares.

In a recent paper, (Coll et al., 2009) come to the conclusion, that Gene expression profiles of MON810 and comparable non-GM maize varieties cultured in the field are more similar than are those of conventional lines. Their bibliography supports this view with numerous peer reviewed publications.

It is therefore no surprise that a natural transgene species has been discovered in a widespread grass genus (Ghatnekar et al., 2006).

(Miller \& Conko, 2004) provide important arguments supporting this view:

The authors raise also in a justified way doubts about the commonly used concept of transgenesis. In the light of pre-recombinant DNA produced in great variety by conventional breeding with thousands of foreign genes.

"In these examples of prerecombinant-DNA genetic improvement, breeders and food producers possess little knowledge of the exact genetic changes that produced the useful trait, information about what other changes have occurred concomitantly in the plant or data on the transfer of newly incorporated genes into animals, humans or microorganisms. Consider, for example, the relatively new man-made wheat 'species' Triticum agropyrotriticum, which resulted from the wide-cross combination of the genomes of bread wheat and a wild grass sometimes called quackgrass or couchgrass (Banks et al., 1993; Sinigovets, 1987) T. agropyrotriticum, which possesses all the chromosomes of wheat as well as the entire genome of the quackgrass, was independently produced for both animal feed and human food in the former Soviet Union, Canada, the United States, France, Germany and China." See also the ASK-FORCE contributions on the web by K. Ammann $2009^{2}$ on the same subject.

\subsection{More recent publications about genomic comparisons of GM- and non-GM crops}

Recent publications demonstrate, that transgenesis e.g. has less impact on the transcriptome of the wheat grain than traditional breeding (Batista et al., 2008;
Baudo et al., 2006; Shewry et al., 2007), (more details: (Ammann, 2008, 2009)).

Two figures may to visualize the lower impact on transcriptome expression of transgenic crops compared to conventional ones:

Volcano plots from (Batista et al., 2008): In all observed cases of the comparison between transgenic and nontransgenic crops the observed alteration was more extensive in the mutagenized than in the transgenic plants:

"Controversy regarding genetically modified (GM) plants and their potential impact on human health contrasts with the tacit acceptance of other plants that were also modified, but not considered as GM products (e.g., varieties raised through conventional breeding such as mutagenesis). What is beyond the phenotype of these improved plants? Should mutagenized plants be treated differently from transgenics? We have evaluated the extent of transcriptome modification occurring during rice improvement through transgenesis versus mutation breeding. We used oligonucleotide microarrays to analyze gene expression in four different pools of four types of rice plants and respective controls: (i) a gamma-irradiated stable mutant, (ii) the M1 generation of a 100-Gy gammairradiated plant, (iii) a stable transgenic plant obtained for production of an anticancer antibody, and (iv) the T1 generation of a transgenic plant produced aiming for abiotic stress improvement, and all of the unmodified original genotypes as controls. We found that the improvement of a plant variety through the acquisition of a new desired trait, using either mutagenesis or transgenesis, may cause stress and thus lead to an altered expression of untargeted genes. In all of the cases studied, the observed alteration was more extensive in mutagenized than in transgenic plants. We propose that the safety assessment of improved plant varieties should be carried out on a case-by-case basis and not simply restricted to foods obtained through genetic engineering." (Batista et al., 2008)

Plots from (Baudo et al., 2006) are also clearly demonstrating, that transcriptome comparisons between transgenic and non-transgenic comparable traits show substantial equivalence.

"Detailed global gene expression profiles have been obtained for a series of transgenic and conventionally bred wheat lines expressing additional genes encoding HMW (high molecular weight) subunits of glutenin, a group of endosperm-specific seed storage proteins known to determine dough strength and therefore bread-making quality. Differences in endosperm and leaf transcriptome profiles between

${ }^{2}$ ASK-FORCE contribution K. Ammann 2009: Regulation: Misconcepts cause high costs and huge delays in regulation of GM crops: http:// www.efb-central.org/index.php/forums/viewthread/59/ 
untransformed and derived transgenic lines were consistently extremely small, when analysing plants containing either transgenes only, or also marker genes. Differences observed in gene expression in the endosperm between conventionally bred material were much larger in comparison to differences between transgenic and untransformed lines exhibiting the same complements of gluten subunits. These results suggest that the presence of the transgenes did not significantly alter gene expression and that, at this level of investigation, transgenic plants could be considered substantially equivalent to untransformed parental lines." (Baudo et al., 2006)

In another recent paper on transcriptomic comparison, (Kogel et al., 2010) come to the following similar conclusions (see also the figures):

"In summary, our results substantially extend observations that cultivar-specific differences in transcriptome and metabolome greatly exceed effects caused by transgene expression. Furthermore, we provide evidence that, (i) the impact of a low number of alleles on the global transcript and metabolite profile is stronger than transgene expression and that, more specifically, (ii) breeding for better adaptation and higher yields has coordinately selected for improved resistance to background levels of root and leaf diseases, and this selection appears to have an extensive effect on substantial equivalence in the field during latent pathogen
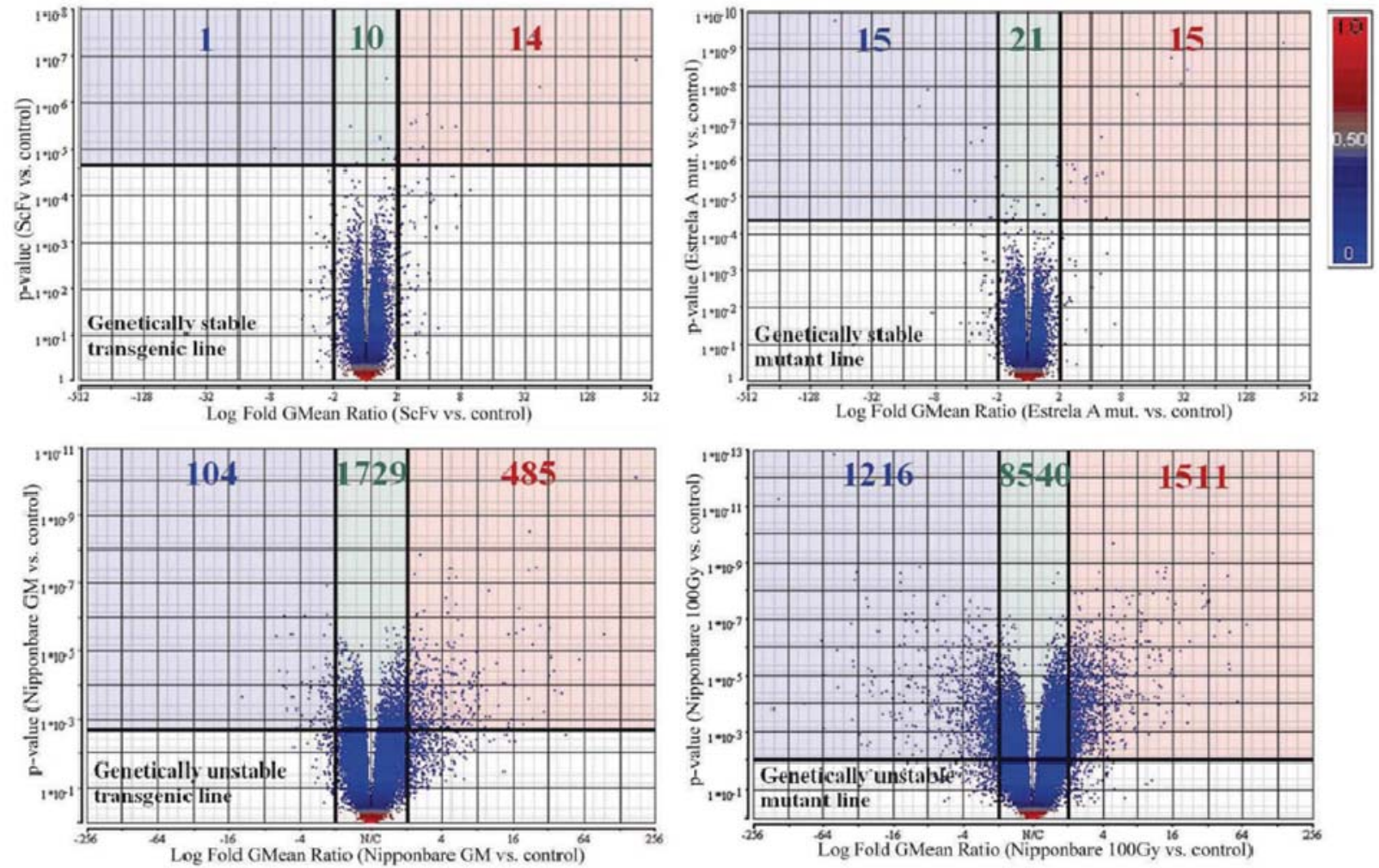

Fig. 1 Volcano plots for differentially expressed genes. Differentially expressed genes appear above the thick horizontal lines. Genes induced_2fold are on the right of the right vertical lines, and the ones repressed_2-fold are on the left of the left vertical line. The numbers corresponding to the differentially expressed genes induced_2-fold for each experiment (red-shadowed area) are red, and those corresponding to the genes repressed_2-fold (blue-shadowed area) are blue. The green-shadowed area corresponds to differentially expressed genes that were up- or downregulated_2-fold (green-colored numbers). Blue-colored genes are those with P between 0 and 0.5 , and red-colored genes are those with $\mathrm{P}$ between 0.5 and 1. From (Batista et al., 2008) 
lines. But only negligible additional differences were found. I know of no instance where a more significant change in gene expression has been caused by a single transgene. However, great variability exists between individual varieties of all the crops mentioned and the obvious explanation for this is that often the breeding objective is to create resistance to external stress factors, and this involves a large number of genes."

Again the same conclusions are drawn by another comprehensive paper of a large international collective of authors (Barros et al., 2010):

"The aim of this study was to evaluate the use of four nontargeted analytical methodologies in the detection of unintended effects that could be derived during genetic manipulation of crops. Three profiling technologies were used to compare the transcriptome, proteome and metabolome of two transgenic maize lines with the respective control line. By comparing the profiles of the two transgenic lines grown in the same location over three growing seasons, we could determine the extent of environmental variation, while the comparison with the control maize line allowed the investigation of effects caused by a difference in genotype. The effect of growing conditions as an additional environmental effect was also evaluated by comparing the Bt -maize line with the control line from plants grown in three different locations in one growing season. The environment was shown to play an important effect in the protein, gene expression and metabolite levels of the maize samples tested where 5 proteins, 65 genes and 15 metabolites were found to be differentially expressed. A distinct separation between the three growing seasons was also found for all the samples grown in one location. Together, these environmental factors caused more variation in the different transcript/protein/ metabolite profiles than the different genotypes." (Barros et al., 2010).

Figure $2 b$ demonstrates no evident differences between GM - and non-GM maize:

Interestingly enough, the parallel short report on the website of USDA (www.isb.vt.edu) was first published
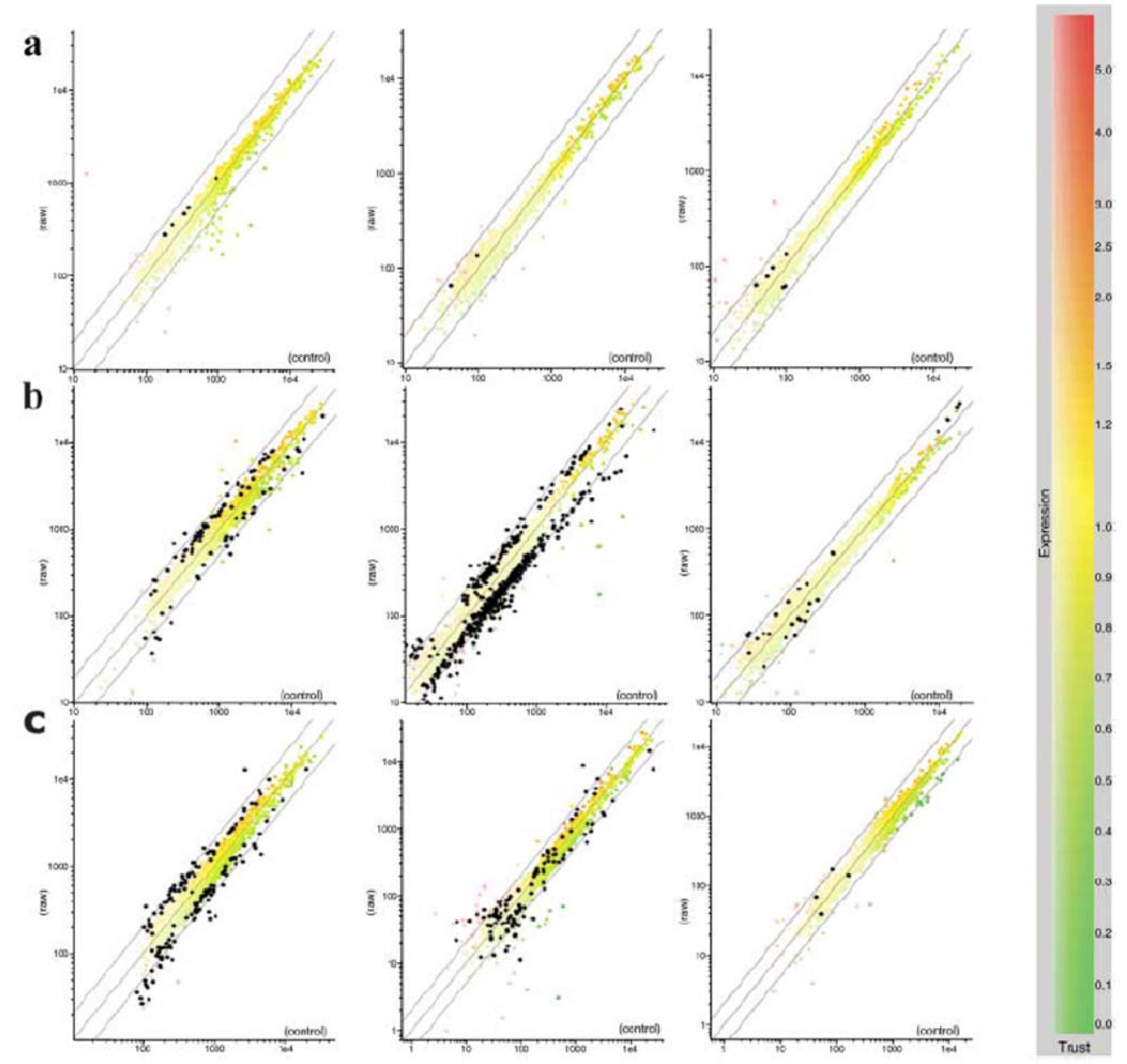

Fig. 2 Scatter plot representation of transcriptome comparisons of: (a) transgenic B102-1-1 line vs. control L88-31 line in endosperm at 14 dpa (left), $28 \mathrm{dpa}$ (middle) or leaf at $8 \mathrm{dpg}$ (right); (b) conventionally bred L88-18 vs. L88-31 line in endosperm at $14 \mathrm{dpa}$ (left), $28 \mathrm{dpa}$ (middle), or leaf at $8 \mathrm{dpg}$ (right); (c) transgenic B102-1-1 line vs. conventionally bred L88-18 line in endosperm at $14 \mathrm{dpa}$ (left), $28 \mathrm{dpa}$ (middle), or leaf at $8 \mathrm{dpg}$ (right). Dots represent the normalized relative expression level of each arrayed gene for the transcriptome comparisons described. Dots in black represent statistically significant, differentially expressed genes (DEG) at an arbitrary cut off $>1.5$. The inner line on each graph represents no change in expression. The offset dashed lines are set at a relative expression cut-off of twofold. In the adjacent colored bar (rectangle on the far right of the figure), the vertical axis represents relative gene expression levels: reds indicate overexpression, yellows average expression, and greens under-expression. Values are expressed as $n$-fold changes. The horizontal axis of this bar represents the degree to which data can be trusted: dark or unsaturated color represents low trust and bright or saturated color represents high trust. From (Baudo et al., 2006). 
(without notifying the authors) under a clearly misleading headline "Molecular Profiling Techniques Detect Unintended Effects in Genetically Engineered Maize", it was subsequently corrected on intervention by the authors to the original headline given in the manuscript: "Molecular Profiling Techniques as Tools to Detect Potential Unintended Effects in Genetically Engineered Maize" (Barros, 2010).

Based on the extensive review of (Wilson et al., 2006), transgenesis results into deletions and insertions in the genome of considerable size, just as radiation mutation breeding can cause: (Meza et al., 2002) show in genetically transformed plants:

"Transgene silencing has been correlated with multiple and complex insertions of foreign DNA, e.g. T-DNA and vector backbone sequences. No striking differences were seen between the TS and C lines. The majority of the deletions are $<75 \mathrm{bp}$, with an average of $36 \mathrm{bp}$. The smallest deletion was 1 bp. In four cases, deletions of $>100 \mathrm{bp}$ were found, the largest of $1537 \mathrm{bp}$. Normally, the deletion represented a continuous stretch of genomic DNA (Fig. $2 A$ and Table 2). A somewhat more complex pattern was observed in only one line (ex $2 \pm 4$ line 8), where a deletion of $35 \mathrm{bp}$ at the integration site was followed by $60 \mathrm{bp}$ of genomic DNA preceding a second deletion of 825 bp." (Meza et al., 2002).

It is one of the most frequent misunderstandings, that transgenesis causes more genomic disturbance than conventional breeding. It is a very frequently
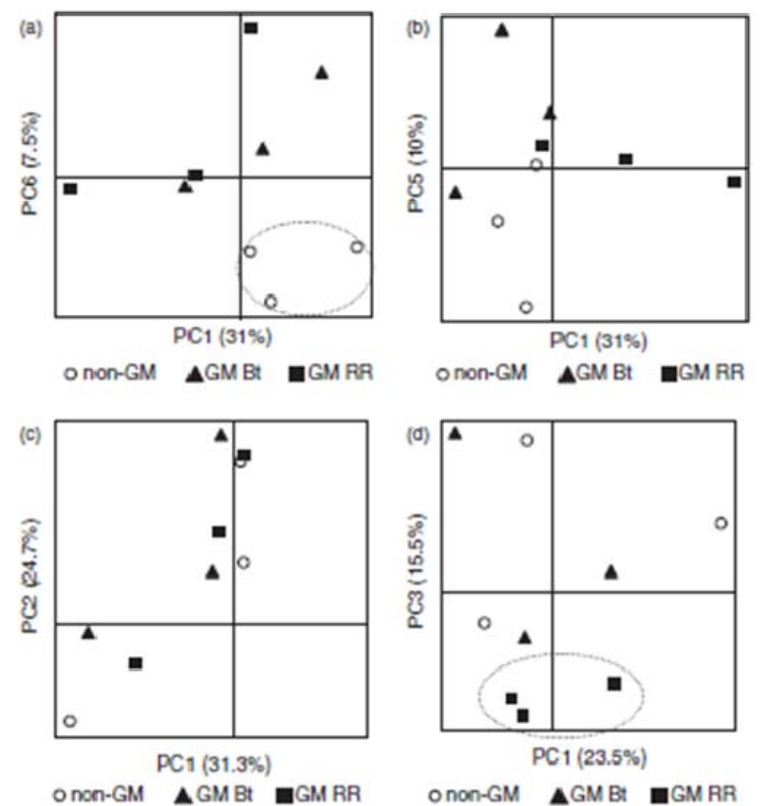

Fig. 3 PCA score plots of maize grown at Petit over three consecutive years. Separation between the non-GM and GM varieties for (a) microarray data, (b) proteomics data, (c) $1 \mathrm{H}-\mathrm{NMR}$ spectra, (d) gas chromatographic/mass spectrometric (GC/MS) metabolite profiles. From (Barros et al., 2010). encountered fundamental mistakes of many risk assessment papers related to GMOs: they lack the baseline comparison - which in the case of environmental risk assessment should also comprise the important elements of agricultural practice. Here, in chapter 3.2. and 3.3. we demand a scientifically founded baseline comparison between the various breeding methods.

\subsection{Natural Genetically Modified Plants, DNA as a highly dynamic system}

As a preface to this chapter, one should realize the fantastic variability of cultivars, here demonstrated with an illustration from (Parrott, 2010) about the already ancient colorful maize landraces (Fig. 4).

It is also ironic and a clear confirmation of green myths, that one of the genetically most altered plants, the sunflower, to find it as a symbol of naturalness for a major political party in Germany (Fig. 5).

It is also worthwhile to visit the site of David Tribe with GMO pundit, he offers an extensive site on genomic comparison between GMOs and non-GMOs, with an impressive collection of "natural transgenic plants" See in particular the series of links under Natural GMOs, parts 1 to 12 and 13 to 26 .

Some of the arguments used by David Tribe are taken up here and enriched with more arguments and references:

\subsection{Dramatic rearrangement of $R$ gene loci: This class of genes diversifies more rapidly than other genes in the crops studies}

One of the major sources of genetic variability (clearly an evolutionary necessity) is described by (Leister, 2005) on the origin, evolution and genetic effects of nuclear insertions of organelle DNA, illustrated in the Fig. 5.

In Box 1, (Leister, 2005) describes in detail the various possibilities of gene flow and reasons for genomic change:

"Box 1. DNA flow between different genetic compartments Six types of DNA transfer are conceivable between the three

${ }^{4}$ David Tribe's blogspot on Natural GMOs: http:// gmopundit2.blogspot.com/2005/12/collected-links-to-scientific.html 

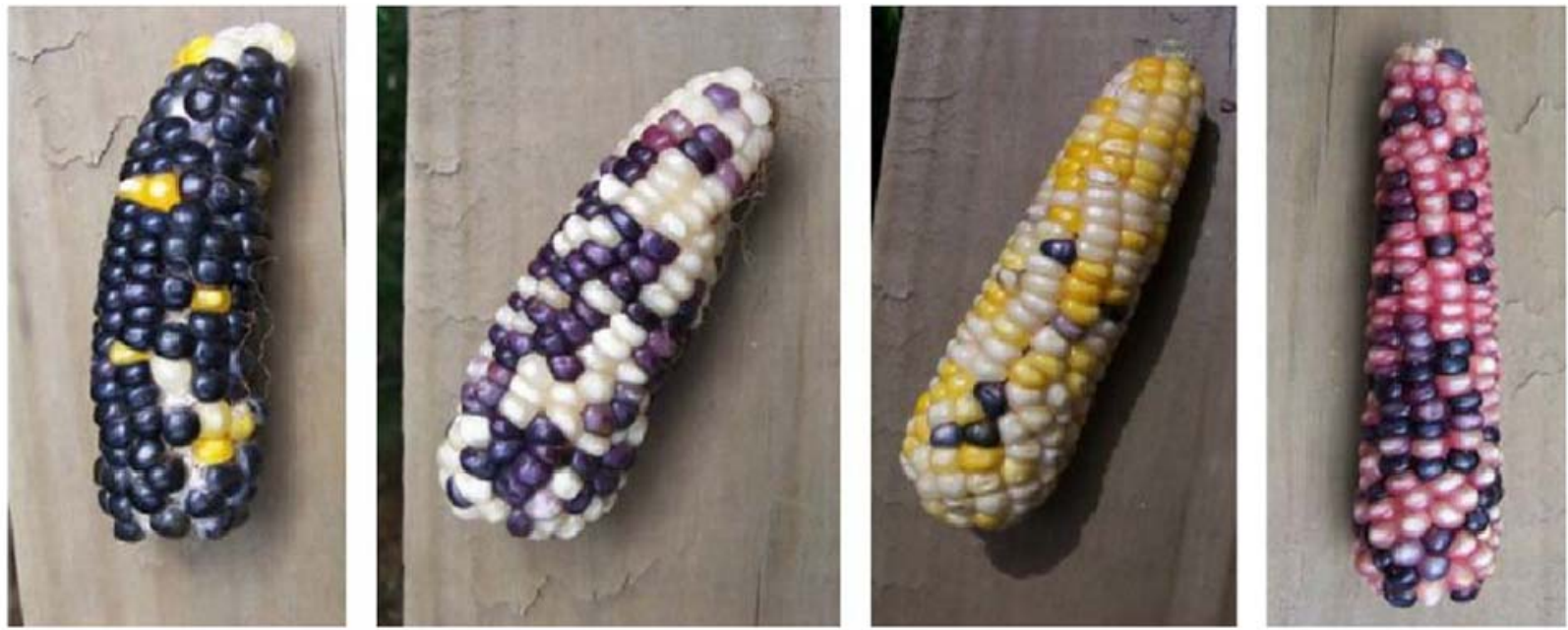

Fig. 4 Maize from the Guatemalan highlands, showing that cross pollination takes place naturally between the landraces. Photos courtesy of Eduardo Roesch, from (Parrott, 2010).

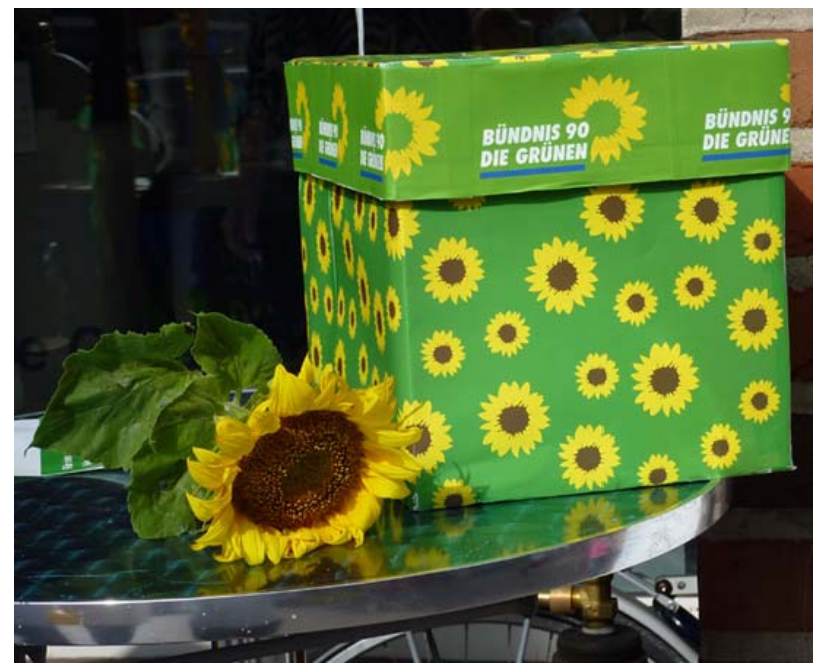

Fig. 5 Sunflowers, Helianthus annuus cultivar, one of the most artificial horticultural plants as a symbol for the political party of the greens from Germany: Bündnis 90, DIE GRÜNEN. http://gruenesenden.de/schlagzeilen/archiv.html

DNA-containing organelles: nucleus, plastid and mitochondrion. In ptDNAs, no sequence of nuclear or mitochondrial origin has yet been detected, indicating that nucleus-to-plastid or mitochondrion-to-plastid transfer occurs extremely rarely or not at all. During the early phase of organelle evolution, organelle-to-nucleus DNA transfer (designated in Figure $I$ as ' $a$ ') resulted in a massive relocation of functional genes to the nucleus: in yeast, as many as $75 \%$ of all nuclear genes could derive from proto-mitochondria [62], whereas $w 4500$ genes in the nucleus of Arabidopsis are of plastid descent [63]. Cases of present-day organelle-tonucleus DNA transfer, revealed by the presence of NUMTs and NUPTs, are known in most species studied so far. Among the few eukaryotic organisms in which norgDNA has not been detected are the malaria mosquito (Anopheles gambiae) and the honeybee (Apis mellifera). Mitochondrial chromosomes contain segments homologous to chloroplast sequences, as well as sequences of nuclear origin, providing indirect evidence for plastid-to-mitochondrion and nucleus-to-

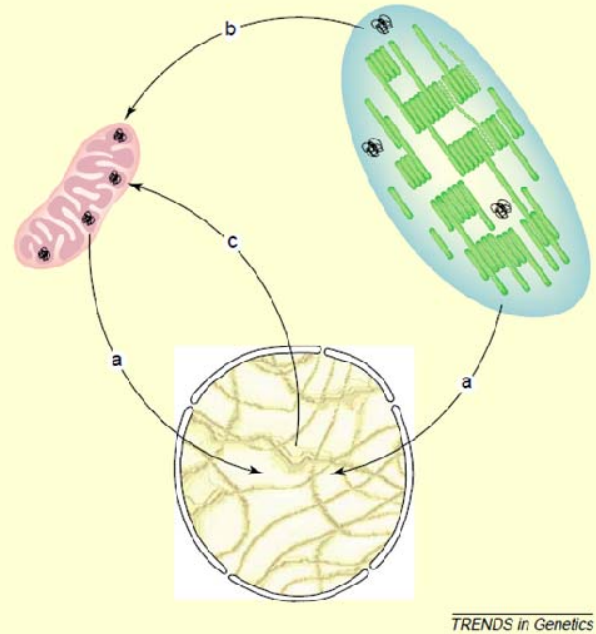

Fig. 6 Schematic overview of known types of intercompartment DNA transfer. (a) Organelle-to-nucleus; (b) chloroplast-to-mitochondrion; (c) nucleus-to-mitochondrion. From (Leister, 2005)

mitochondrion transfer of DNA (Figure I: ' $b$ ' and ' $c$ '). Thus, $a$ few percent of the mtDNA of flowering plants derives from ptDNA, whereas retrotransposons seem to be the major source of nucleus-derived mtDNA. Interestingly, although plastid-to-mitochondrion and nucleus-tomitochondrion DNA transfer have been detected in almost all plant mitochondrial chromosomes sequenced so far [64,65], there is no evidence for the incorporation of nDNA into the mitochondrial genome of maize [66]."

Conclusions of an earlier paper of (Leister et al., 1998):

"Our data suggest a dramatic rearrangement of $R$ gene loci between related species and implies a different mechanism for nucleotide binding site plus leucine-rich repeat gene evolution compared with the rest of the monocot genome"

And further on in the same paper:

"Here we describe the isolation and characterization of NBS- 
$L R R$ homologues via $P C R$ from two monocot species, rice and barley, based on structurally conserved motifs in dicot NBS$L R R R$ genes. We have analyzed their sequence diversity and their linkage to genetically characterized $R$ genes. The results from a comparative mapping in rice, barley, and foxtail millet indicates a rapid evolution of $R$ genes in each species and suggests possible mechanisms to generate diversity in resistance loci." And:

"At present, rapid sequence divergence and ectopic recombination are equally possible mechanisms to explain the lack of intraspecific syntenic relationships detected with our set of R-like gene probes. Regardless of whether the former or latter (or both) mechanism drives the evolution of monocot NBSLRR genes, the data shown here provides strong evidence that this class of genes diversifies more rapidly than the rest of the tested monocot genomes." (Leister et al., 1998)

\subsection{Jumping Genes: Their dynamics falsify the erroneous picture of regulators that DNA is a stable string of genes}

The seemingly absolute novelty of genetic engineering on the molecular level has been contested already in the early days of molecular biology in the 1930s and 1950s with the discovery of cellular systems for genome restructuring discovered with the classic papers of McClintock (McClintock, 1930, 1953).

1. A case of semi-sterility in Zea mays was found to be associated with a reciprocal translocation (segmental interchange) between the second and third smallest chromosomes.

2. Through observations of chromosome synapsis in early meiotic prophases of plants heterozygous for the interchange it has been possible to locate approximately the point of interchange in both chromosomes. The interchange was found to be unequal.

3. An analysis of the chromosome complements in the microspores of plants heterozygous for the interchange indicated that of the four chromosomes constituting a ring, those with homologous spindle fiber attachment regions can pass to the same pole in anaphase I and do so in a considerable number of the sporocytes.

And in the paper of 1953, usually cited as the classic publication, leading decades later, including her relentless fight for the "jumping genes concept": Here the full summary of her paper:

"Previous studies of the origin and mode of expression of genic instability at a number of known loci in maize led to the following conclusions. Extragenic units, carried in the chromosomes, are responsible for altering genic expression.
When one such unit is incorporated at the locus of a gene, it may affect genic action. The altered action is detected as a mutation. Subsequent changes at the locus, initiated by the extragenic unit, again can result in change in genic action ; consequently, a new mutation may be recognized. The extragenic units undergo transposition from one location to another in the chromosome complement. It is this mechanism that is responsible for the origin of instability at the locus of a known gene; insertion of an extragenic unit adjacent to it initiates the instability. The extragenic units represent systems in the nucleus that are responsible for controlling the action of genes. They have specificity in that the mode of control of genic action in any one case is a reflection of the particular system in operation at the locus of the gene. One extragenic system controlling genic expression is composed of two interacting units. It is the so-called Dissociation-Activator (Ds-Ac) system. Both Ds and Ac undergo transposition. The Ds component, when inserted at the locus of a gene, is responsible for modification of genic expression. Subsequent changes at the locus, initiated by $D$ s, result in further modification of genic expression. The Ac component in this two-unit system controls when the changes at Ds will occur. From the conclusions stated above, it was anticipated that the Ds-Ac system could operate at any locus of known genic action. This is because the Ds unit may be transposed to various locations in the chromosome complement. To obtain this type of instability at any one locus of kn,own genic action, it is only necessary to provide adrquate means for its detection. The methods used to obtain and detect this type of instability at the Al locus in chromosome 3 and at the A2 locus in chromosome 5 are described. A detailed analysis of one such case is presented in this report."

Later commentaries of Fedoroff were summarizing the scientific achievements of McClintock, acknowledging her scientific merits: (Fedoroff, 1992, 1994; Fedoroff et al., 1995; Fedoroff, 1984; Fedoroff, 1991). Especially in the review published in the Scientific American, transposons are well summarized as a generally occurring phenomenon, having changed considerably the concept of genomics, this is well illustrated in the fact of the multicolored maize kernels (Fig. 7).

See a photo from a landrace preserved as a cultivar from Thusis, Switzerland, visualizing the dynamics of transposition (Fig. 8).

More comments on McClintocks scientific breakthrough in (Lewin, 1983; Shapiro, 1997), the latter probably the first to coin the term 'natural genetic engineering'. Unfortunately, the dynamics of life DNA processes was not taken properly into account when the Cartagena protocol on biosafety was conceived. 


\subsection{Helitrons contribute to the lack of gene colinearity observed in modern maize inbreds}

It was David Tribe in his blogspot on natural transgenics part 7 linking helitrons to natural GMO's ${ }^{5}$

"Until recently, it was assumed that the order of gene sequences within modern maize would be virtually invariant. Recent discoveries have shown that gene co-linearity is not always the case. Several laboratories (1-3) have found DNA regions rich in gene sequences that are present in some maize inbred lines but absent at homologous sites in other lines. This variation, termed "intraspecific violation of genetic colinearity" or "plus/minus genetic polymorphism," was shown by (Lal \& Hannah, 2005) in a recent issue of PNAS to be caused by a newly described transposable element family termed Helitrons."

In a recent review, (Lal et al., 2009) summarize the importance of a recently discovered superfamily of transposable elements. The authors critically analyze the proposed mechanisms of Helitron transposition, their impact on genome evolution and the process by which these enigmatic elements capture and multiply host genes. Intriguingly, maize Helitrons share striking structural similarity

to bacterial integrons. These elements capture gene sequences via site-specific recombination and generate circular intermediates (Hall \& Collis, 1995). Both Helitrons and integrons are mobile, lack terminal
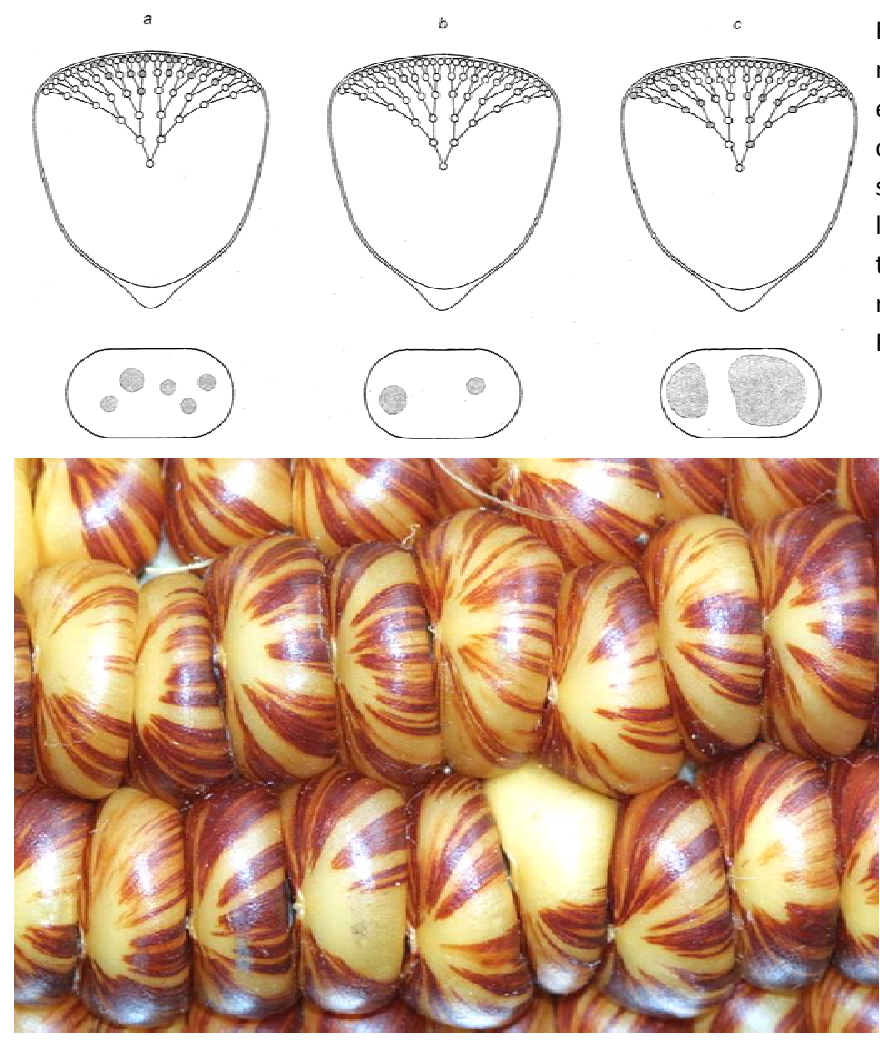

Fig. 8 Landrace preserved as a cultivar from Thusis, Switzerland, visualizing the colorful dynamics of transposition: Photo Klaus Ammann

repeats and cause no duplication of host genome sequence upon insertion.

\subsection{Polyploids, Alloploids in Flowering Plants}

In his blog series part 9, David Tribe sums up polyploidisation dynamics of higher plants ${ }^{6}$ :

"During only the past decade [i.e post 1985] molecular approaches have provided a wealth of data that have dramatically reshaped views of polyploid evolution, providing a much more dynamic picture than traditionally espoused. In particular, molecular data:

(i) demonstrate that both autopolyploids and allopolyploids exhibit a high frequency of recurrent formation (multiple origin),

(ii) reveal that multiple polyploidization events within species have significant genetic and evolutionary implications, and

(iii) contradict the traditional view of autoploidy as being rare and maladaptive (Soltis \& Soltis, 1993).

Perhaps one of the most important contributions of molecular data to the study of polyploid evolution is the documentation that a single polyploid species may have separate, independent origins from the same diploid progenitor species.

Multiple origins of polyploids have now been documented in bryophytes (Wyatt et al., 1988) and in $>40$ species of ferns (e.g., (Werth et al., 1985) and (Ranker et al., 1989) and angiosperms (e.g., refs. (Brochmann et al., 1992; Doyle et al., 1990; Soltis et al., 1995; Song \& Osborn, 1992). In fact, molecular data indicate that multiple origins of polyploids are the rule and not the exception (Soltis \& Soltis, 1993). In

Fig. 7 Development time and frequency of transposition differ in mutations caused by the insertion of different defective Spm elements. If transposition takes place late in the development, the clones of revertent cells are small and therefore so are the pigmented spots (a). If transposition takes place at about the same time but at a lower frequency, there are fewer such clones and fewer spots (b). If the transposition that resores gene function takes place earlier, the revertant clones and the spots of the pigmented tissue are larger (c). From (Fedoroff, 1984).

David Tribes blogspot No. 7: http:// gmopundit.blogspot.com/2006/01/natural-gmos-part-7-nanobot-

${ }^{6}$ David Tribes blogspot No. 9: http:// gmopundit.blogspot.com/2006/01/natural-gmos-part-9different.html genetic.html 
several species studied in detail with molecular markers, recurrent polyploidization was shown to occur with great frequency during short time spans and in small geographic areas ((Brochmann et al., 1992; Soltis et al., 1995). For example, Tragopogon mirus and Tragopogon miscellus may have formed as many as 9 and 21 times, respectively, in a small region of eastern Washington and adjacent Idaho during just the past 50 years (Soltis et al., 1995). The frequent recurrence of polyploidization also has major evolutionary implications, suggesting that polyploids are much more genetically dynamic than formerly envisioned."

Polyploidy is one of the most distinctive and widespread modes of speciation in higher plants. Thirty to $70 \%$ of angiosperms, including many important crop plants, are estimated to have polyploidy in their lineages (Song et al., 1995), again a strong argument for the high dynamics of the genome of higher plants.

\subsection{Horizontal Geneflow between Pro- Caryotes and Eu-Caryotes}

There is a rich literature documenting - on an evolutionary scale - that horizontal transfer of genes (HGT) between pro-caryotes and eu-caryotes are not uncommon: However, according to (Keeling \& Palmer, 2008) many records of HGT (Consortium, 2001) are not confirmed by phylogenetic analysis proving incongruent sequences (Stanhope et al., 2001). This means that potentially, molecular processes can transfer foreign genes, so - actually, all living organisms are in that sense "transgenic organisms", but only considering evolutionary time scales of millions of years time span for the transfer event. To be clear, there is no evidence of horizontal gene transfer coming from the relatively new practice in modern breeding methods of genetic engineering (Smalla \& Sobecky, 2002; Smalla \& Vogel, 2007). Even the much publicized case of HGT with a transgene in the human guts is based on clearly wrong interpretation and false claims (Ammann, 2002). However, for mitochondrial DNA things are different:

According to (Archibald \& Richards, 2010), mitrochondrial DNA can be exchanges rather frequently:

"Parasitic plants and their hosts have proven remarkably adept at exchanging fragments of mitochondrial DNA. Two recent studies (Mower et al., 2010; Richardson \& Palmer, 2007) provide important mechanistic insights into the pattern, process and consequences of horizontal gene transfer, demonstrating that genes can be transferred in large chunks and that gene conversion between foreign and native genes leads to intragenic mosaicism. A model involving duplicative horizontal gene transfer and differential gene conversion is proposed as a hitherto unrecognized source of genetic diversity."

The conclusion from this chapter 4.5. is again that gene exchange in the course of evolution has been proven, and thus "evolutionary transgenes" are part of nature. The conclusion again: Transgenesis belongs to nature and it is scientifically not justified to make a fundamental distinction between natural organisms (strictly without transgenes) and artificial organisms containing trangenes with methods of targeted genetic engineering.

\subsection{Some conventional breeding causes lots of genomic alteration}

One should also take into account, that many of the conventional breeding methods such as colchicination (Awoleye et al., 1994; Barnabás et al., 1999) and radiation mutation breeding (Reynolds et al., 2000; Shirley et al., 1992) are obviously more damaging to the genome (Schouten \& Jacobsen, 2007), and it is in addition not possible to clearly define what impact the un-targeted process could have caused. (Molnar et al., 2009) reported in detail about radiation treatment of the chromosome morphology of wheat hybrids: Dicentric chromosomes, fragments, and terminal translocations were most frequently induced by gamma-radiation, but centric fusions and internal exchanges were also more abundant in the treated plants than in the control amphiploids. The irradiated amphiploids formed fewer seeds than untreated plants, but on the other hand normal levels of fertility were recovered in their offspring. On the positive side the authors are confident that intergenomic translocations will facilitate the successful introgression of drought resistance and other alien traits in bred wheat. But it has to be admitted that repair mechanisms on the DNA level are powerful (Baarends et al., 2001; Dong et al., 2002; Morikawa \& Shirakawa, 2001). It is only logical that opposition within organic farming towards genetic engineering is now expanding also to some of those conventional breeding methods, some go even so far as to reject marker assisted breeding - typically for the organic agriculture scene, this trend is based on the myth of "intrinsic integrity of the genome", for which term it is not possible in the literature to find a proper scientific definition based on comparisons (Ammann, 2008). The addition of rejected breeding methods would ultimately lead to an absurd situation, where most of 
the modern time traits would have to be rejected and breeding would be forced to start from scratch.

Basically, many of the first generation GM crops should be today subject to a professional debate on deregulation, and there is good and sturdy reason to state that many of these GM crops should not have been treated in such a special way in the first place, they can be compared in their risk potential to many crops created with traditional methods.

This should not be misunderstood as a plea for general deregulation of GM crops, rather for a strict and science based risk based regulation focusing also on products, not on processes alone.

Somatic hybridization also deserves a short mention here, the method enabled the artificial hybridization of crops which have no genomic natural compatibility, see the review of (Waara \& Glimelius, 1995), Progeny analysis of some hybrid combinations also reveals inter-genomic translocations which may lead to the introgression of the alien genes. Furthermore, fusion techniques enable the resynthesis of allopolyploid crops to increase their genetic variability and to restore ploidy level and heterozygosity after breeding at reduced ploidy level in polyploid crops.

\subsection{Regulatory dissent over molecular differences causes transatlantic divide}

This actually includes a critical questioning about some basic rules of the United Nations Convention on Biological Diversity (CBD): transgenic crops of the first generation should not have been generally subjected to regulation purely based on the process of transgenesis alone; rather it would have been wiser to have a close look at the products in each case, as John Maddox already proposed in 1992 in an editorial in Nature (Anonymous, 1992). This is also the view of Canadian regulators (Andree, 2002; Berwald et al., 2006; Macdonald \& Yarrow, 2002), where the novelty of the crop is the primary trigger for regulation. This transatlantic (and transoceanic) contrast has been commented by many (Aerni et al., 2009; Bennett et al., 1986; Kalaitzandonakes et al., 2005; Ramjoue, 2007a, b; Snyder et al., 2008; Thro, 2004), and although for many years a solution and mediation seemed to be too difficult, contrasts can be overcome:
In a letter ${ }^{7}$ to the executives of the Convention on Biological Diversity (CBD), the Public Research and Regulation Initiative (PRRI) is asking for a scientific discussion in order to exempt a list of GM crops from the expensive regulatory process for approval, here only the final statement:

"Bearing in mind that the method of transformation itself is neutral, i.e. that there are no risks related to process of transformation, PRRI believes that there are several types of LMOs and traits for which - on the basis of the characteristics of the host plant, the functioning of the inserted genes and experience with the resulting GMO - it can be concluded that they are as safe as its conventional counterpart with respect to potential effects on the environment, taking also into account human health."

In a recent paper, an indiscriminate continuation of food biosafety research is questioned on the basis of all the above arguments by Herman et al. (Herman et al., 2009) with good reason:

"Compositional studies comparing transgenic crops with nontransgenic crops are almost universally required by governmental regulatory bodies to support the safety assessment of new transgenic crops. Here we discuss the assumptions that led to this requirement and lay out the theoretical and empirical evidence suggesting that such studies are no more necessary for evaluating the safety of transgenic crops than they are for traditionally bred crops."

\subsection{Perspectives for a dissolution of this divide}

These new perspectives create hope, that solutions can be found:

In a first phase some of the widespread transgenic crops like transgenic maize with the Cry1Ab endotoxin should be exempt from regulation, which is indeed possible according to art. 7.4 in the Cartagena Protocol. In COP-MOP5 ${ }^{8} 2010$ in Japan it should be possible, to amend the protocol with the introduction of a dynamics which allows to start the regulatory process with an initial phase focusing on the process of transgenesis, first following procedures proposed for non-target insects by (Raybould, 2010; Romeis et al., 2008), but in due time shifting later the focus on the product, making it possible to abbreviate the regulatory process wherever possible and feasible.

\footnotetext{
7PRRI letter : http://www.pubresreg.org/index.php? option=com_docman\&task=doc_download \&gid $=490$

${ }^{8}$ Fifth meeting of the Conference of the Parties serving as the Meeting of the Parties to the Cartagena Protocol on Biosafety (COP-MOP 5), 11 - 15. 10. 2010 Nagoya, Japan http://bch.cbd.int/protocol/ meetings/
} 


\section{A conceptual framework is proposed by IFPRI/ISNAR}

in 2002, the International Service for National Agricultural Research (McLean et al., 2002), a careful evaluation of process-based versus product-based triggers in regulatory action can also lead to a merger of both seemingly so contrasting concepts into a legalized decision making process on which trigger should be chosen in a case by case strategy:

"Process-based triggers are the rule in almost all countries that have developed national biosafety regulatory systems; there are exceptions, however, where the novelty of the trait determines the extent of regulatory oversight and not the process by which the trait was introduced. While such a product-based approach to defining the object of regulation is truest to the scientific principle that biotechnology is not inherently more risky than other technologies that have a long and accepted history of application in agriculture and food production, it is less prescriptive than process-based regulatory systems."

Many of the debates on those two concepts suffer from a lack of clear-cut definitions, it will be important to have a close look at the Canadian regulatory system and the definition of PNTs (Plants with Novel Traits). In Canada, the trigger for risk-assessment is the novelty of the plant rather than the methods used to produce it.

\subsection{Cited literature}

Aerni, P., Rae, A., \& Lehmann, B. (2009) Nostalgia versus Pragmatism? How attitudes and interests shape the term sustainable agriculture in Switzerland and New Zealand. Food Policy, 34, 2, pp 227-235 http:// www.sciencedirect.com/science/article/B6VCB4V1MFKR-1/2/b72610f6397bc5572a076cbe0ae3e599 AND http://www.botanischergarten.ch/Sustainability/ Aerni-Nostalgia-versus-Pragmatism-2009.pdf

Ammann, K. (2002) University of Newcastel report summaries: no significant horizontal transgene transfer detected in human guts. In Berne Debates blog, University of Newcastle report summaries. Klaus Ammann, Bern http://www.ask-force.org/web/HorizontalGT/AmmannNewcastle-Human-Guts-2002.PDF

Ammann, K. (2008) Feature: Integrated farming: Why organic farmers should use transgenic crops. New Biotechnology, 25, 2, pp 101 - 107 http://www.botanischergarten.ch/NewBiotech/ Ammann-Integrated-Farming-Organic-2008.publ.pdf AND DOI: http://dx.doi.org/10.1016/j.nbt.2008.08.012

Ammann, K. (2009) Feature: Why farming with high tech methods should integrate elements of organic agriculture. accepted, corrected proof. New
The difficulties start there, where a clear definition of PNTs is needed to come to a decision: It means that plants produced using recombinant DNA techniques, chemical mutagenesis, cell fusion, cis-genics or any other in-vitro technique leading to a novel trait, need to undergo risk assessment in the Canadian system. No wonder the Canadian definition of novel traits is rather wordy, but remains broad minded:

"A plant variety/genotype possessing characteristics that demonstrate neither familiarity nor substantial equivalence to those present in a distinct, stable population of a cultivated seed in Canada and that have been intentionally selected, created or introduced into a population of that species through a specific genetic change."

\subsection{Conclusions}

There can be no doubt that product-based regulatory approaches are truest to the scientific principle that biotechnology is not inherently more risky than other technologies that have a long and accepted history of application in agriculture and food production, it is also less prescriptive than process-based systems, see McLean et al. (McLean et al., 2002).

Biotechnology, 4, pp http://dx.doi.org/10.1016/j.nbt.2009.06.933 AND http://www.botanischergarten.ch/NewBiotech/ Integrated-Farming-Biotech-Org-20090724-publ.pdf

Andree, P. (2002) The biopolitics of genetically modified organisms in Canada. Journal of Canadian Studies-Revue D Etudes Canadiennes, 37, 3, pp 162-191 <Go to $|S|>: / /$ WOS:000236751100009 AND http:// www.botanischergarten.ch/Regulation/AndreeBiopolitics--GMO-Canada.pdf

Anonymous (1992) Products pose no special risks just because of the processes used to make them. Nature, $356,6364, \mathrm{pp} 1-2$ http://dx.doi.org/10.1038/356001b0 AND http:// www.botanischergarten.ch/Regulation/Anonymous-USRegulation-Nature-1992.pdf

Arber, W. (1994)

MOLECULAR EVOLUTION: COMPARISON OF NATURAL AND ENGINEERED GENETIC VARIATIONS. Pontifical Academy of Sciences Scripta Varia, 103, pp 90-101 http://as8978.http.sasm3.net/roman_curia/ pontifical_academies/acdscien/archivio/s.v.103_chagas/ part3.pdf AND http://www.botanischergarten.ch/ Genomics/Arber-Molecular-Evolution-Comparison-PAS1994.pdf

Arber, W. (2000) Genetic variation: molecular mechanisms 
and impact on microbial evolution. Fems Microbiology

Reviews, 24, 1, pp 1-7

<Go to $|S|>: / / 000084915900001$ AND http://

www.botanischergarten.ch/Mutations/Arber-Gen-

Variation-FEMS-2000.pdf

Arber, W. (2002) Roots, strategies and prospects of functional genomics. Current Science, 83, 7, pp 826-828 $<$ Go to $|S|>: / / 000178662800019$ and http:// www.botanischergarten.ch/Mutations/ArberComparison-2002.pdf

Arber, W. (2003) Elements for a theory of molecular evolution. Gene, 317, 1-2, pp 3-11

$<$ Go to $|S|>: / / 000186667000002$ and http:// www.botanischergarten.ch/Mutations/Arber-Gene-3172003.pdf

Arber, W. (2004) Biological evolution: Lessons to be learned from microbial population biology and genetics. Research in Microbiology, 155, 5, pp 297-300 <Go to ISI >://000222736200001 AND http:// www.botanischergarten.ch/Mutations/Arber-EvolutionLessons-2004.pdf

Arber, W. (2010) Genetic engineering compared to natural genetic variations. New Biotechnology, In Press, Corrected Proof, pp http://www.sciencedirect.com/science/article/B8JG4504JYNT-2/2/a7e6edd02959e1b3167158dd264f24a2 AND http://www.ask-force.org/web/Vatican-PAS-NBTpubl/Arber-Genetic-Engineering-PAS-2010.pdf

Archibald, J. \& Richards, T. (2010) Gene transfer: anything goes in plant mitochondria. Bmc Biology, 8, 1, pp 147 http://www.biomedcentral.com/1741-7007/8/147 AND http://www.ask-force.org/web/HorizontalGT/ArchibaldGene-Transfer-Mitochondria-2010.pdf

Awoleye, F., Vanduren, M., Dolezel, J., \& Novak, F.J. (1994) NUCLEAR-DNA CONTENT AND IN-VITRO INDUCED SOMATIC POLYPLOIDIZATION CASSAVA (MANIHOTESCULENTA CRANTZ) BREEDING. Euphytica, 76, 3, pp 195-202

<Go to ISI>://WOS:A1994PK33000005 AND http:// www.botanischergarten.ch/Radiation-Mutants/Awoleye -Nuclear-DNA-content-1994.pdf

Baarends, W.M., van der Laan, R., \& Grootegoed, J.A. (2001) DNA repair mechanisms and gametogenesis.

Reproduction, 121, 1, pp 31-39

$<$ Go to ISI >://WOS:000168328900004 AND http:// www.botanischergarten.ch/Genomics/Baarends-DNARepair-Mechanisms-2001.pdf

Banks, P.M., Xu, S.J., Wang, R.R.C., \& Larkin, P.J. (1993) VARYING CHROMOSOME COMPOSITION OF 56CHROMOSOME WHEAT X THINOPYRUM-INTERMEDIUM PARTIAL AMPHIPLOIDS. Genome, 36, 2, pp 207-215 $<$ Go to ISI>://A1993LA74500001 AND http:// www.botanischergarten.ch/Genomics/Banks-VaryingChromosome-Composition-1993.pdf

Barnabás, B., Obert, B., \& Kovács, G. (1999) Colchicine, an efficient genome-doubling agent for maize (Zea mays L.) microspores cultured in anthero. Plant Cell Reports, 18 10 , pp 858-862

http://dx.doi.org/10.1007/s002990050674 AND http:// www.botanischergarten.ch/Mutations/BarnabasColchicine-Genome-Doubling-1999.pdf

Barros, E. (2010) Molecular Profiling Techniques as Tools to Detect Potential Unintended Effects in Genetically Engineered Maize (revised title), Molecular Profiling Techniques Detect Unintended Effects in Genetically Engineered Maize (old title). ISB News Report, May 2010, pp 4-7

http://www.botanischergarten.ch/Genomics/Barros-ISB -News-Report-Genomics-Maisze-old-201005.pdf AND http://www.botanischergarten.ch/Genomics/Barros-ISB -News-Report-Genomics-Maize-new-4-7.pdf

Barros, E., Lezar, S., Anttonen, M.J., Dijk, J.P.v., Röhlig, R.M., Kok, E.J., \& Engel, K.-H. (2010)

Comparison of two GM maize varieties with a nearisogenic non-GM variety using transcriptomics, proteomics and metabolomics. Plant Biotechnology Journal, 8, 4, pp 436-451 http://dx.doi.org/10.1111/j.1467-7652.2009.00487.x AND http://www.botanischergarten.ch/Genomics/ Barros-Comparison-GM-crops-2010.pdf

Batista, R., Saibo, N., Lourenco, T., \& Oliveira, M.M. (2008) Microarray analyses reveal that plant mutagenesis may induce more transcriptomic changes than transgene insertion. Proceedings of the National Academy of Sciences of the United States of America, 105, 9, pp 3640-3645

<Go to ISI >://WOS:000253846500082 AND http:// www.botanischergarten.ch/Genomics/BatistaMicroarray-Analysis-2008.pdf AND http:// www.botanischergarten.ch/Genomics/TransgenesisComparison-Slides.pdf AND Http:// www.botanischergarten.ch/Genomics/TransgenesisComparison-Slides.ppt

Baudo, M.M., Lyons, R., Powers, S., Pastori, G.M., Edwards, K.J., Holdsworth, M.J., \& Shewry, P.R. (2006)

Transgenesis has less impact on the transcriptome of wheat grain than conventional breeding. Plant Biotechnology Journal, 4, 4, pp 369-380 $<$ Go to ISI >://000238256500001 AND http:// www.botanischergarten.ch/Organic/Baudo-Impact2006.pdf

Bennett, D., Glasner, P., \& Travis, D. (1986) The Politics of Uncertainty Routledge \& Kegan Paul plc., IS: 0-71020503-1, pp 218

Berg, P., Baltimore, D., Brenner, S., Roblin, R.O., \& Singer, M.F. (1975) SUMMARY STATEMENT OF ASILOMAR CONFERENCE ON RECOMBINANT DNA-MOLECULES. Proceedings of the National Academy of Sciences of the United States of America, 72, 6, pp 1981-1984 <Go to ISI >://WOS:A1975AG70300001 AND http:// www.botanischergarten.ch/History/Berg-SummaryStatement-Asilomar-1975.pdf

Berg, P. \& Singer, M. (1995) THE RECOMBINANT-DNA 
CONTROVERSY - 20 YEARS LATER. Bio-Technology, 13 10, pp 1132-1134

<Go to ISI>://WOS:A1995RY31800031 AND http:// www.botanischergarten.ch/History/Berg-RecombinantDNA-Twenty-years-later-1995.pdf

Berwald, D., Carter, C.A., \& Gruere, G.P. (2006) Rejecting new technology: The case of genetically modified wheat. American Journal of Agricultural Economics, 88, 2, pp 432-447 <Go to |SI >://WOS:000236716200012 AND http:// www.botanischergarten.ch/Regulation/BerwaldRejecting-New-Technology-2006.pdf

Brochmann, C., Soltis, P.S., \& Soltis, D.E. (1992) RECURRENT FORMATION AND POLYPHYLY OF NORDIC POLYPLOIDS IN DRABA (BRASSICACEAE). American Journal of Botany, 79, 6, pp 673-688 <Go to $|S|>: / /$ WOS:A1992HZ92600009

Chassy, B.M. (2007) The history and future of GMOs in food and agriculture. Cereal Foods World, 52, 4, pp 169-172 $<$ Go to ISI >://000248207400002 AND http:// www.botanischergarten.ch/History/Chassy-HistoryFuture-2007.pdf

Coll, A., Nadal, A., Collado, R., Capellades, G., Messeguer, J., Melé, E., Palaudelmàs, M., \& Pla, M. (2009) Gene expression profiles of MON810 and comparable non-GM maize varieties cultured in the field are more similar than are those of conventional lines. Transgenic Research, 18, 5, pp 801-808 http://dx.doi.org/10.1007/s11248-009-9266-z AND http://www.botanischergarten.ch/Genomics/Coll-GeneExpressioin-Profiles-Comparable-2009.pdf

Consortium, I.H.G.S. (2001) Initial sequencing and analysis of the human genome. Nature, 409,6822, pp 860-921 http://dx.doi.org/10.1038/35057062 AND http:// www.nature.com/nature/journal/v409/n6822/ suppinfo/409860a0_S1.html AND http://www.askforce.org/web/HorizontalGT/International-SequencingHuman-Genome-Nature-2001.pdf

Dong, C.M., Whitford, R., \& Langridge, P. (2002) A DNA mismatch repair gene links to the Ph2 locus in wheat. Genome, 45, 1, pp 116-124 <Go to $|S|>: / / W O S: 000173553000016$ AND http:// www.botanischergarten.ch/Genomics/Dong-DNAMismatch-Repair-Gene-2002.pdf

Doyle, J.J., Doyle, J.L., Brown, A.H., \& Grace, J.P. (1990) Multiple origins of polyploids in the Glycine tabacina complex inferred from chloroplast DNA polymorphism. Proceedings of the National Academy of Sciences of the United States of America, 87, 2, pp 714-717 http://www.pnas.org/content/87/2/714.abstract AND http://www.botanischergarten.ch/Genomics/DoyleMultiple-Origins-1990.pdf

Fedoroff, N. (1992) MCCLINTOCK,BARBARA, THE GENETICIST, THE GENIUS, THE WOMAN - OBITUARY. Cell, 71, 2, pp 181-182

$<$ Go to ISI>://WOS:A1992JU39500001
Fedoroff, N. (1994) MCCLINTOCK,BARBARA (JUNE 16, 1902 SEPTEMBER 2, 1992). Proceedings of the American Philosophical Society, 138, 3, pp 431-445 <Go to ISI>://WOS:A1994PH68500011 AND NEBIS 20090920

Fedoroff, N., Schlappi, M., \& Raina, R. (1995) EPIGENETIC REGULATION OF THE MAIZE SPM TRANSPOSON.

Bioessays, 17, 4, pp 291-297

<Go to ISI>://WOS:A1995QV74600004

Fedoroff, N.V. (1984) Transposable genetic elements in maize [Corn, Zea mays]. Scientific American, 250, pp 64 $-74$ http://www.botanischergarten.ch/Genomics/Fedorofftransposable-Elements-Maize-1984.pdf

Fedoroff, N.V. (1991) The Restless Gene - How the Colors of Indian Corn Have Led to an Understanding of Wandering DNA. Sciences-New York, 31, 1, pp 22-28 $<$ Go to ISI>://WOS:A1991EM86800018

Ferreira, S.J., Senning, M., Sonnewald, S., Kessling, P.M., Goldstein, R., \& Sonnewald, U. (2010) Comparative transcriptome analysis coupled to X-ray CT reveals sucrose supply and growth velocity as major determinants of potato tuber starch biosynthesis. BMC Genomics, 11, pp <Go to |SI>://WOS:000275291800004 AND http:// www.botanischergarten.ch/Genomics/FerreiraComparative-Transcriptome-Analysis-Potato-2010.pdf

Friedberg, E.C. (2007) The writing life of James D. Watson. Adler Museum Bulletin, 33, 2, pp 3-16 http://www.botanischergarten.ch/History/FriedbergWriting-Life-James-Watson-2007.pdf

Ghatnekar, L., Jaarola, M., \& Bengtsson, B.O. (2006) The introgression of a functional nuclear gene from Poa to Festuca ovina. Proceedings: Biological Sciences, 273, 1585, pp 395 - 399

http://www.botanischergarten.ch/Genomics/Ghatnekar -Transgen-Festuca.pdf

Hackett, P. (2002) Genetic Engineering: What are We Fearing? Transgenic Research, 11, 2, pp 97-99 http://dx.doi.org/10.1023/A:1015292423744 AND http://www.botanischergarten.ch/Genomics/HackettGE-What-are-we-fearing-2002.pdf

Hall, R.M. \& Collis, C.M. (1995) Mobile gene cassettes and integrons: capture and spread of genes by site-specific recombination. Molecular Microbiology, 15, 4, pp 593600 http://dx.doi.org/10.1111/j.1365-2958.1995.tb02368.x AND http://www.ask-force.org/web/Genomics/HallMobile-Gene-Cassettes-1995.pdf

Herman, R.A., Chassy, B.M., \& Parrott, W. (2009) Compositional assessment of transgenic crops: an idea whose time has passed. Trends in Biotechnology, In Press, Corrected Proof, pp http://www.sciencedirect.com/science/article/B6TCW4X26XP1-1/2/bcfd547d5f12695fc76c4fc5886ba9fc AND 
http://www.botanischergarten.ch/Regulation/HermanCompositional-Analysis-2009.pdf

Kalaitzandonakes, N., Marks, L., \& Vickner, S.S. (2005) Sentiments and acts towards genetically modified foods. International Journal of Biotechnology, 7, 1-3, pp 161177

http://www.inderscience.com/search/index.php? action=record\&rec_id=6452\&prevQuery $=\& p s=10 \& m=o r$ AND http://www.botanischergarten.ch/Regulation/ Kalaitzandonakes-Sentiments-Acts-2005.pdf

Keeling, P.J. \& Palmer, J.D. (2008) Horizontal gene transfer in eukaryotic evolution. Nature Reviews Genetics, 9, 8, pp 605-618

<Go to ISI>://WOS:000257758400011 AND http:// www.botanischergarten.ch/HorizontalGT/Keeling-HGTEukaryotic-Evolution-2008.pdf

Klug, A. (2004) The Discovery of the DNA Double Helix. Journal of Molecular Biology, 335, 1, pp 3-26 http://www.sciencedirect.com/science/article/B6WK74B41W2K-4/2/181d9023626e6f1c425f384c9f3d31a4 AND http://www.botanischergarten.ch/History/KlugDiscovery-DNA-Double-Helix-2004.pdf AND http:// www.botanischergarten.ch/History/Klug-Discovery-DNA -Double-Helix-corrigendum-2004.pdf

Kogel, K.-H., Voll, L.M., Schaefer, P., Jansen, C., Wu, Y., Langen, G., Imani, J., Hofmann, J.r., Schmiedl, A., Sonnewald, S., von Wettstein, D., Cook, R.J., \& Sonnewald, U. (2010) Transcriptome and metabolome profiling of field-grown transgenic barley lack induced differences but show cultivar-specific variances. Proceedings of the National Academy of Sciences, 107, 14, pp 6198-6203 <Go to ISI>://WOS:000276374400016 AND http:// www.ask-force.org/web/Genomics/KogelTranscriptome-Metabolome-2010.pdf AND http:// www.ask-force.org/web/Genomics/KogelTranscriptome-Metabolome-Supporting-2010.pdf

Lal, S., Oetjens, M., \& Hannah, L.C. (2009) Helitrons: Enigmatic abductors and mobilizers of host genome sequences. Plant Science, 176, 2, pp 181-186 <Go to ISI>://WOS:000262566600003 AND http:// www.ask-force.org/web/Genomics/Lal-HelitronsEnigmatic-Abductors-2009.pdf

Lal, S.K. \& Hannah, L.C. (2005) Helitrons contribute to the lack of gene colinearity observed in modern maize inbreds. Proceedings of the National Academy of Sciences of the United States of America, 102, 29, pp 9993-9994

http://www.pnas.org/content/102/29/9993.short AND http://www.botanischergarten.ch/Genomics/LalHelitrons-contribute-2005.pdf

Leister, D. (2005) Origin, evolution and genetic effects of nuclear insertions of organelle DNA. Trends in Genetics, 21, 12, pp 655-663 <Go to ISI>://WOS:000233672700005 AND http:// www.ask-force.org/web/Genomics/Leister-OriginEvolution-Genetic-Effects-2005.pdf
Leister, D., Kurth, J., Laurie, D.A., Yano, M., Sasaki, T., Devos, K., Graner, A., \& Schulze-Lefert, P. (1998) Rapid reorganization of resistance gene homologues in cereal genomes. Proceedings of the National Academy of Sciences of the United States of America, 95, 1, pp 370375 <Go to ISI >://WOS:000071429500070 AND http:// www.botanischergarten.ch/Genomics/Leister-RapidReorganization-Reisitance.1998.pdf

Lewin, R. (1983) A Naturalist of the Genome. Science, 222, 4622, pp 402-405 <Go to ISI>://WOS:A1983RM23800018 AND http:// www.botanischergarten.ch/Genomics/Lewin-NaturalistGenome-McClintock-1983.pdf

Macdonald, P. \& Yarrow, S. (2002) Regulation of Bt crops in Canada, Iguassu Falls, Brazil Academic Press Inc Elsevier Science 8th International Colloquium on Invertebrate Pathology and Microbial Control/35th Annual Meeting of the SIP/6th International Conference on Bacillus Thuringiensis Ed. pp 93-99 $<$ Go to $|S|>$ ://000183491000002 AND http:// www.botanischergarten.ch/Regulation/MacDonaldRegulation-Bt-crops-Canada-2003.pdf

McClintock, B. (1930) A cytological demonstration of the location of an interchange between two nonhomologous chromosomes of Zea mays. Proceedings of the National Academy of Sciences of the United States of America, 16, pp 791-796 <Go to ISI >://WOS:000201970600143 AND http:// www.botanischergarten.ch/Genomics/McClintockCytological-Interchange-Location-1930.pdf

McClintock, B. (1953) Induction of Instability at Selected Loci in Maize. Genetics, 38, 6, pp 579-599 <Go to ISI>://WOS:A1953XW86100004 AND http:// www.botanischergarten.ch/Genomics/McClintockInstability-Maize-1953.pdf

McLean, M.A., Frederick, R.J., Traynor, P.L., Cohen, J.I., \& Komen, J. (2002) A Conceptual Framework for Implementing Biosafety: Linking Policy, Capacity, and Regulation, ISNAR, International Service for National Agricultural Research pp 1-12 ISNAR Briefing Papers Washington DC. (Report) ftp://ftp.cgiar.org/isnar/publicat/bp-47.pdf AND http:// www.botanischergarten.ch/Regulation/McLeanConceptual-Framework-ISNAR-47-2002.pdf

Meza, T.J., Stangeland, B., Mercy, I.S., Skarn, M., Nymoen, D.A., Berg, A., Butenko, M.A., Hakelien, A.M., Haslekas, C., Meza-Zepeda, L.A., \& Aalen, R.B. (2002) Analyses of single-copy Arabidopsis T-DNA-transformed lines show that the presence of vector backbone sequences, short inverted repeats and DNA methylation is not sufficient or necessary for the induction of transgene silencing. Nucleic Acids Research, 30, 20, pp 4556-4566 <Go to |S|>://WOS:000178826700034 AND http:// www.ask-force.org/web/Genomics/Meza-AnalysesArabidopsis-2002.pdf 
Miller, H.I. \& Conko, G. (2004) Chasing 'transgenic' shadows. Nat Biotech, 22, 6, pp 654-655 http://dx.doi.org/10.1038/nbt0604-654 AND http:// www.botanischergarten.ch/Bt/Miller-Chasingtransgenic-shadows-2004.pdf

Molnar, I., Benavente, E., \& Molnar-Lang, M. (2009) Detection of intergenomic chromosome rearrangements in irradiated Triticum aestivum - Aegilops biuncialis amphiploids by multicolour genomic in situ hybridization. Genome, 52, 2, pp 156-165 <Go to ISI >://WOS:000265606300006 AND http:// www.botanischergarten.ch/Mutations/MolnarDetection-Interngenomic-rearrangements-2009.pdf

Morikawa, K. \& Shirakawa, M. (2001) Three-dimensional structural views of damaged-DNA recognition: T4 endonuclease $\mathrm{V}$, E. coli Vsr protein, and human nucleotide excision repair factor XPA (vol 460, pg 257, 2000). Mutation Research-DNA Repair, 485, 3, pp 267268

<Go to ISI :://WOS:000167838200009 AND http:// www.botanischergarten.ch/Genomics/MorikawaStructural-Views-Damaged-DNA-2000.pdf

Mower, J., Stefanovic, S., Hao, W., Gummow, J., Jain, K., Ahmed, D., \& Palmer, J. (2010) Horizontal acquisition of multiple mitochondrial genes from a parasitic plant followed by gene conversion with host mitochondrial genes. Bmc Biology, 8, 1, pp 150 http://www.biomedcentral.com/1741-7007/8/150 AND http://www.ask-force.org/web/HorizontalGT/MowerHorizontal-acquisition-Mitochondrial-2010.pdf

National-Research-Council (1989) Field Testing Genetically Modified Organism. Framework for Decisions, Committee on Scientific Evaluation of the Introduction of Genetically Modified Microorganisms and Plants into the Environment, National Research Council edn. The National Academy Press, pp 184 free online reading http://www.nap.edu/ catalog/1431.html

Parrott, W. (2010) Genetically modified myths and realities. New Biotechnology, 27, 5, pp 545-551 http://www.sciencedirect.com/science/article/B8JG4506RN94-2/2/41a40cb121ad20dd44db6f76d34f1bd5 AND http://www.ask-force.org/web/Vatican-PASStudyweek-Elsevier-publ-20101130/Parrott-Wayne-PASGenetically-Modified-Myths-20101130-publ.pdf

Ramjoue, C. (2007a) The transatlantic rift in genetically modified food policy. Journal of Agricultural \& Environmental Ethics, 20, 5, pp 419-436 <Go to |S|>://WOS:000248855000003 AND http:// www.botanischergarten.ch/Regulation/RamjoueTransatlantic-Rift-2007.pdf

Ramjoue, C. (2007b) The transatlantic rift in genetically modified food policy. Doctoral Thesis, University of Zurich, Zurich Thesis, pp 263 http://www.botanischergarten.ch/Regulation/RamjoueThesis-Transatlantic-Rift-2007.pdf

Ranker, T.A., Haufler, C.H., Soltis, P.S., \& Soltis, D.E. (1989)
GENETIC-EVIDENCE FOR ALLOPOLYPLOIDY IN THE NEOTROPICAL FERN HEMIONITIS-PINNATIFIDA (ADIANTACEAE) AND THE RECONSTRUCTION OF AN ANCESTRAL GENOME. Systematic Botany, 14, 4, pp 439447

<Go to ISI>://WOS:A1989AW04900001 AND http:// www.botanischergarten.ch/Genomics/Ranker-GeneticEvidence-Allopolyploidy-1989.pdf

Raybould, A.F. (2010) Reducing uncertainty in regulatory decision-making for transgenic crops: More ecological research or shrewder environmental risk assessment? GM crops, 1, 1, pp 1-7

http://www.landesbioscience.com/journals/gmcrops/ article/9776 AND http://www.botanischergarten.ch/ Regulation/Raybould-Reducing-uncertainty-2010.pdf

Reynolds, M.P., van Ginkel, M., \& Ribaut, J.M. (2000) Avenues for genetic modification of radiation use efficiency in wheat. Journal of Experimental Botany, 51, pp 459-473 $<$ Go to ISI >://WOS:000085386600017 AND http:// www.botanischergarten.ch/DroughtResistance/ Reynolds-Avenues-Genetic-Modification-2000.pdf

Richardson, A.O. \& Palmer, J.D. (2007) Horizontal gene transfer in plants. Journal of Experimental Botany, 58, 1, pp 1-9

$<$ Go to $|S|>$ ://WOS:000243063800002 AND http:// www.ask-force.org/web/HorizontalGT/RichardsonHorizonta-Gene-Transfer-2007.pdf

Romeis, J., Bartsch, D., Bigler, F., Candolfi, M., Gielkens, M.C., Hartley, S.E., Hellmich, R., Huesing, J.E., Jepson, P.C., Layton, R.J., Quemada, H., Raybould, A., Rose, R., Schiemann, J., Sears, M.K., Shelton, M., Sweet, J., Vaituzis, Z., \& Wolt, J.D. (2008) Assessment of risk of insect-resistant transgenic crops to nontarget arthropods. Nature Biotechnology, 26, 2, pp 203-208 http://dx.doi.org/10.1038/nbt1381 AND http:// www.nature.com/nbt/journal/v26/n2/suppinfo/ nbt1381_S1.html AND http:// www.botanischergarten.ch/Bt/Romeis-Nontarget2008.pdf

Schouten, H.J. \& Jacobsen, E. (2007) Are mutations in genetically modified plants dangerous? Journal of Biomedicine and Biotechnology, pp <Go to ISI >://WOS:000252054100001 AND http:// www.botanischergarten.ch/Regulation/SchoutenMutations-Dangerous-2007.pdf

Shapiro, J.A. (1997) Genome organization, natural genetic engineering and adaptive mutation. Trends in Genetics, 13, 3, pp 98-104 http://www.sciencedirect.com/science/article/B6TCY3RH119N-13/2/8e4f005e42c9889d6cc09ab2f3f2fd25 AND http://www.botanischergarten.ch/Genomics/ Shapiro-Natural-Genetic-Engineering-1997.pdf

Shewry, P.R., Baudo, M., Lovegrove, A., \& Powers, S. (2007) Are $\mathrm{GM}$ and conventionally bred cereals really different? Trends in Food Science \& Technology, 18, 4, pp 201-209 $<$ Go to $|S|>: / / W O S: 000245784600003$ AND http:// 
www.botanischergarten.ch/Wheat/Shewry-Are-GMConvent-Cereals-different-2007.pdf

Shirley, B.W., Hanley, S., \& Goodman, H.M. (1992) EFFECTS OF IONIZING-RADIATION ON A PLANT GENOME ANALYSIS OF 2 ARABIDOPSIS TRANSPARENT-TESTA MUTATIONS. Plant Cell, 4, 3, pp 333-347 <Go to ISI>://WOS:A1992HL04000011 AND http:// www.ask-force.org/web/Genomics/Shirley-InonizingRadiation-Arabidopsis-1992.pdf

Sinigovets, M.E. (1987) THE CYTOGENETIC STRUCTURE OF A 56-CHROMOSOME TRITICUM-AESTIVUM - ELYTRIGIA INTERMEDIA HYBRIDS. Genetika, 23, 5, pp 854-862 <Go to ISI>://WOS:A1987H772100012

Smalla, K. \& Sobecky, P.A. (2002) The prevalence and diversity of mobile genetic elements in bacterial communities of different environmental habitats: insights gained from different methodological approaches. Fems Microbiology Ecology, 42, 2, pp 165175

<Go to ISI>://000179450100002 AND http:// www.botanischergarten.ch/HorizontalGT/SmallaReview-HGT-2002.pdf

Smalla, K. \& Vogel, T.M. (2007) Presentation of the thematic issue on horizontal gene transfer. Environmental Biosafety Research, 6, 1-2, pp 1-2 <Go to ISI>://BIOSIS:PREV200700602019 AND http:// www.botanischergarten.ch/HorizontalGT/SmallaHorizontal-Geneflow-2007.pdf

Snyder, L.U., Gallo, M., Fulford, S.G., Irani, T., Rudd, R., DiFino, S.M., \& Durham, T.C. (2008) European Union's Moratorium Impact on Food Biotechnology: A Discussion-Based Scenario. Journal of Natural Resources and Life Sciences Education, 37, pp 27-31 <Go to ISI>://BIOSIS:PREV200900043152 AND http:// www.botanischergarten.ch/Regulation/Snyder-UnruhEuropean-Moratorium-2008.pdf

Soltis, D.E. \& Soltis, P.S. (1993) MOLECULAR-DATA AND THE DYNAMIC NATURE OF POLYPLOIDY. Critical Reviews in Plant Sciences, 12, 3, pp 243-273 <Go to ISI>://WOS:A1993LJ92200004 AND http:// www.botanischergarten.ch/Genomics/Soltis-MolecularData-Dynamic-1993.pdf

Soltis, P.S., Plunkett, G.M., Novak, S.J., \& Soltis, D.E. (1995) GENETIC-VARIATION IN TRAGOPOGON SPECIES ADDITIONAL ORIGINS OF THE ALLOTETRAPLOIDS TMIRUS AND T-MISCELLUS (COMPOSITAE). American Journal of Botany, 82, 10, pp 1329-1341 <Go to ISI >://WOS:A1995TA45600015 AND http:// www.botanischergarten.ch/Genomics/Soltis-GeneticVariation-Tragopogon-1995.pdf

Song, K., Lu, P., Tang, K., \& Osborn, T.C. (1995) Rapid genome change in synthetic polyploids of Brassica and its implications for polyploid evolution. Proceedings of the National Academy of Sciences of the United States of America, 92, 17, pp 7719-7723

http://www.pnas.org/content/92/17/7719.abstract AND http://www.ask-force.org/web/Genomics/Song-
Rapid-Genome-Change-Brassica-1995.pdf

Song, K. \& Osborn, T.C. (1992) POLYPHYLETIC ORIGINS OF BRASSICA-NAPUS - NEW EVIDENCE BASED ON ORGANELLE AND NUCLEAR RFLP ANALYSES. Genome, 35, 6, pp 992-1001 <Go to ISI>://WOS:A1992KD50000014 AND http:// www.botanischergarten.ch/Genomics/SongPolyphlyletic-Origins-Brassica-1962.pdf

Stanhope, M.J., Lupas, A., Italia, M.J., Koretke, K.K., Volker, C., \& Brown, J.R. (2001) Phylogenetic analyses do not support horizontal gene transfers from bacteria to vertebrates. Nature, 411, 6840, pp 940-944 http://dx.doi.org/10.1038/35082058 AND http:// www.nature.com/nature/journal/v411/n6840/ suppinfo/411940a0_S1.html AND http://www.askforce.org/web/HorizontalGT/Stanhope-PhylogeneticAnalysis-2001.pdf

Thro, A.M. (2004) Europe on transgenic crops: How public plant breeding and eco-transgenics can help in the transatlantic debate. Commentary. In AgBioForum, Vol. 7, pp. $142-148$ http://www.agbioforum.org/v7n3/v7n3a06-thro.htm AND http://www.botanischergarten.ch/Thro-EuropeTransgenic-Crops-2004.pdf

van Bueren, E.T.L., Ostergard, H., Goldringer, I., \& Scholten, O. (2008) Plant breeding for organic and sustainable, low-input agriculture: dealing with genotypeenvironment interactions. Euphytica, 163, 3, pp 321322

$<$ Go to $|S|>$ ://000258654800001 AND http:// www.botanischergarten.ch/Organic/Lammerts-PlantBreeding-Interactions-2008.pdf

Van Bueren, E.T.L. \& Struik, P.C. (2004) The consequences of the concept of naturalness for organic plant breeding and propagation. Njas-Wageningen Journal of Life Sciences, 52, 1, pp 85-95 <Go to ISI >://000226051800007 AND http:// www.botanischergarten.ch/Organic/Van-BuerenConsequences-2004.pdf

Van Bueren, E.T.L. \& Struik, P.C. (2005) Integrity and rights of plants: Ethical notions in organic plant breeding and propagation. Journal of Agricultural \& Environmental Ethics, 18, 5, pp 479-493 <Go to ISI >://000231949300003 AND http:// www.botanischergarten.ch/Organic/Van-Bueren-Ethical -2005.pdf

Van Bueren, E.T.L., Struik, P.C., Tiemens-Hulscher, M., \& Jacobsen, E. (2003) Concepts of intrinsic value and integrity of plants in organic plant breeding and propagation. Crop Science, 43, 6, pp 1922-1929 $<$ Go to $|S|>: / / 000186477700003$ AND http:// www.botanischergarten.ch/Organic/Van-BuerenIntrinsic-2003.pdf

Waara, S. \& Glimelius, K. (1995) THE POTENTIAL OF SOMATIC HYBRIDIZATION IN CROP BREEDING. Euphytica, 85, 1-3, pp 217-233 
<Go to ISI >://WOS:A1995TF37600028 AND http:// www.ask-force.org/web/Genomics/Waara-PotentialSomatic-Hybridization-1995.pdf

Watson, J.D. \& Crick, F.H.C. (1953a) GENETICAL IMPLICATIONS OF THE STRUCTURE OF DEOXYRIBONUCLEIC ACID. Nature, 171, 4361, pp 964967

<Go to ISI>://WOS:A1953UA43900005 AND http:// www.botanischergarten.ch/History/Watson-CrickGenetical-Implications-DNA-1953.pdf

Watson, J.D. \& Crick, F.H.C. (1953b) MOLECULAR STRUCTURE OF NUCLEIC ACIDS - A STRUCTURE FOR DEOXYRIBOSE NUCLEIC ACID. Nature, 171, 4356, pp 737-738 <Go to ISI>://WOS:A1953UA43400007 AND http:// www.botanischergarten.ch/History/Watson-CrickMolecular-Structure-Nucleic-Acids-1953.pdf

Werth, C.R., Guttman, S.I., \& Eshbaugh, W.H. (1985) RECURRING ORIGINS OF ALLOPOLYPLOID SPECIES IN ASPLENIUM. Science, 228, 4700, pp 731-733 <Go to ISI>://WOS:A1985AGH4200034 AND http:// www.botanischergarten.ch/Genomics/Werth-Recurring-
Origins-Asplenium-1965.pdf

Wilkins, M.H.F., Seeds, W.E., Stokes, A.R., \& Wilson, H.R. (1953) Helical Structure of Crystalline Deoxypentose Nucleic Acid. Nature, 172, 4382, pp 759-762 http://dx.doi.org/10.1038/172759b0 AND http:// www.botanischergarten.ch/History/Wilkins-HelicalStructure-Desoxypentose-1953.pdf

Wilson, A., Latham, J., \& Steinbrecher, R. (2006) Transformation-induced mutations in transgenic plants: Analysis and biosafety implications. . Biotechnology and Genetic Engineering Reviews 23, 11, pp 1-26 http://www.botanischergarten.ch/Radiation-Mutants/ Wilson-Transformation-Induced-Mutations-2006.pdf

Wyatt, R., Odrzykoski, I.J., Stoneburner, A., Bass, H.W., \& Galau, G.A. (1988) ALLOPOLYPLOIDY IN BRYOPHYTES MULTIPLE ORIGINS OF PLAGIOMNIUM-MEDIUM. Proceedings of the National Academy of Sciences of the United States of America, 85, 15, pp 5601-5604 <Go to ISI>://WOS:A1988P574600056 AND http:// www.botanischergarten.ch/Genomics/WyattAllopolyploidy-Bryophytes-1988.pdf 